\title{
ADAT SEBAGAI BUDAYA KEARIFAN LOKAL UNTUK MEMPERKUAT EKSISTENSI ADAT KE DEPAN
}

\author{
H. Munir Salim
}

Dosen Fakultas Syariah dan Hukum UIN Alauddin Makassar

\begin{abstract}
The development of an increasingly tight and hard growth, causing forgetting the background to the law. For a moment we look back in the history of law in the world, particularly in Indonesia, to ensure that the laws are born, live, grow and develop in people who have strong views and ideology as a source of ground rules that are not written. However, to grow and develop and be maintained as is the custom of ancestor through his ancestors. These habits lived continuously from generation to generation successor. Habits become a tradition in the life of society, both as individuals and groups, it creates mores of a particular group called the Indigenous Village.

Desa Adat an indigenous group is still very limited scope of its territory, because of the geographical and territorial factors. Both factors are decisive role in Desa Adat position is concerned. Where the customs area has its own characteristics that are not affected by circumstances beyond the group members. Specificity in each Indigenous Village/Traditional Area as shades, signs/emblem Indigenous Village/Indigenous relevant region can be seen in the social life of everyday whether in terms of art, clothing, food, festivities, royal, skill patterns of life in the character/characters as well as natural attractions.

From the joints of which can be highlighted among the best of its kind as featured and acceptable and attractive to members of local indigenous groups as well as people from outside the group and foreigners from abroad.
\end{abstract}

Keywords:

Local Wisdom, Existence, Desa Adat/Adat Regions

\begin{abstract}
Abstrak
Perkembangan yang semakin kencang dan keras pertumbuhannya, menyebabkan terlupakannya latar belakang lahirnya hukum. Sejenak kita menengok ke belakang dalam sejarah perkembangan hukum di dunia, khususnya di Indonesia, dapat dipastikan bahwa hukum itu lahir, hidup, tumbuh dan berkembang dalam masyarakat yang mempunyai pandangan dan ideologi yang kuat sebagai sumber
\end{abstract}


pijakan peraturan-peraturan yang tidak tertulis. Namun, tumbuh dan berkembang serta dipertahankan sebagai kebiasaan dari leluhur melalui nenek moyangnya. Kebiasaan-kebiasaan tersebut dijalani secara berkesinambungan dari generasi ke generasi penerusnya. Kebiasaan-kebiasaan menjadi tradisi dalam kehidupan, masyarakat, baik sebagai individu maupun kelompok, maka terciptalah adatistiadat suatu kelompok tertentu yang disebut dengan Adat Desa.

Adat Desa merupakan kelompok adat yang masih sangat terbatas lingkup wilayahnya, karena faktor geografis dan teritorialnya. Kedua faktor tersebut sangat menentukan peran dalam posisi Adat Desa yang bersangkutan. Dimana adat istiadat daerah mempunyai ciri khas tersendiri yang tidak terpengaruh dengan keadaan di luar anggota kelompoknya. Kekhususan pada setiap Adat Desa/Adat Daerah sebagai corak, tanda/lambang Adat Desa/Adat Daerah yang bersangkutan dapat dilihat dalam kehidupan sosial sehari-hari apakah dalam hal kesenian, pakaian, makanan, pesta perayaan, kerajaan, keterampilan pola kehidupan di watak/karakter serta wisata alam.

Dari sendi-sendi kehidupan tersebut dapat ditonjolkan mana di antara yang terbaik dari yang baik sebagai unggulan dan dapat diterima serta diminati oleh anggota kelompok adat setempat maupun orang-orang dari luar kelompok maupun orang asing dari mancanegara.

Kata Kunci:

Kearifan Lokal, Eksistensi, Adat Desa/Adat Daerah

\section{A. PENDAHULUAN}

\section{Latar Belakang}

Tearifan lokal sebagai hasil produksi kebiasaan yang hidup dan tumbuh bersama masyarakat Adat Desa / Adat Daerah dan diimplementasikan dalam

Lkehidupan sosial dan kekerabatan dalam masyarakat. Khususnya masyarakat Indonesia yang masih sangat kuat dan eksistensinya tertanam sejak dulu hingga sampai sekarang menjadi pedoman dalam aktifitas dalam kehidupan masyarakat yang sangat terkait dengan hukum yang berlaku dalam wilayah Negara Kesatuan Republik Indonesia yakni Hukum Positif.

\section{Tujuan Penulisan}

Tujuan penulisan dari makalah ini adalah untuk mengetahui Hukum Adat, Kearifan lokal, serta bagaimanakah Adat dimasa yang akan datang?

\section{B. PEMBAHASAN}

Dalam situasi kondisi lingkungan Indonesia menghasilkan keanekaragaman ekosistem beserta sumber daya alam, melahirkan manusia Indonesia yang berkaitan 
erat dengan kondisi alam dalam melakukan berbagai aktivitas untuk menunjung kelangsungan hidupnya. Manusia Indonesia memandang sumber alam sebagai guru pemberi petunjuk gaya hidup masyarakat, yang terlahir dalam bentuk kebiasaan Adat Istiadat alami yang dituangkan menjadi adat kehidupan yang berorientasi pada sifat alam yang berkembang sesuai keberadaannya (sunnahtullah) dan menjadi pelajaran yang berharga dari seorang guru dalam kehidupan bermasyarakat.

Kearifan lokal merupakan warisan nenek moyang kita dalam tata nilai kehidupan yang menyatu dalam bentuk religi, budaya dan adat istiadat. Dalam perkembangannya masyarakat melakukan adaptasi terhadap lingkungannya dengan mengembangkan suatu kearifan yang berwujud pengetahuan atau ide, peralatan, dipadu dengan norma adat, nilai budaya, aktivitas mengelola lingkungan guna mencukupi kebutuhan hidupnya.

Jika melihat evolusi hubungan manusia dengan alam di masa lampau telah terbentuk suatu hubungan yang harmonis yang disebut pan cosmism dimana manusia berusaha untuk hidup selaras dengan alam. Dalam pandangan manusia pada masa itu, alam itu besar dan sakral karena itu harus dipelihara sehingga tidak terjadi kerusakan alam dan berakibat negatif bagi manusia itu sendiri. Dalam merealisasikan gagasan itu manusia menciptakan pamali-pamali atau etika bagaimana bertindak dan bertingkah laku terhadap alam. Hampir sebagian besar etnis di Negara ini memiliki aturan-aturan dimaksud yang disebut sebagai kearifan lingkungan.

Masyarakat lokal yang hidup seimbang berdampingan dengan alam memiliki pengetahuan yang diwariskan turun-temurun tentang bagaimana memenuhi kebutuhan hidup tanpa merusak alam.

Kearifan tradisional yang bersifat lokal sesuai dengan daerahnya masingmasing merupakan salah satu warisan budaya yang ada di masyarakat Indonesia dan secara turun-temurun dilaksanakan oleh kelompok masyarakat bersangkutan, menjelaskan bahwa dari sisi lingkungan hidup keberadaan kearifan lokal tradisional sangat menguntungkan karena secara langsung ataupun tidak langsung dalam memelihara lingkungan serta mencegah terjadinya kerusakan lingkungan. Kearifan lokal sebagai produk kolektif masyarakat, difungsikan guna mencegah keangkuhan dan keserakahan manusia dalam mengeksploitasi sumberdaya alam tanpa merusak kelestarian hidup. Peningkatan mutu pengelolaan lingkungan hidup memerlukan komitmen etika masyarakat lokal bersama stakeholder dalam berperilaku adaptif memanfaatkan sumberdaya alam didukung kebijakan pembangunan yang pro lingkungan hidup.

Masih banyak sekali bentuk-bentuk kebiasaan adat istiadat dari Daerah Adat yang ada di peloso Nusantara, menampilkan kebiasaan ciri khas masing-masing yang bernilai tinggi baik maupun kualitas dari hasil karya kerajinan anak-anak bangsa yang tersebar di Daerah Adat yang berada pada kelompok masyarakat adat tersebut. 
Hal tersebut tidak bisa dirinci secara mendetail karena banyaknya bentuk, corak, dan macamnya yang berbeda-beda apakah dalam bentuk makanan, pakaian khas, produksi hasil kerajinan tangan, acara pesta perayaan, kesenian, maupun wisata alam tempat rekreasi yang masing-masing Daerah Adat mempertahankan sebagai kekhasan Daerah, dan dapat dipromosikan keluar sebagai kearifan lokal bagi daerah yang bersangkutan.

Seiring perjalanannya waktu, pemerintah mengayomi serta memberikan perhatian penuh dari fenomena kehidupan masyarakat untuk mengatur secara teratur dan damai dalam masyarakat, maka secara bertahap pemerintah mengeluarkan aturan yang mengatur sesuai kebutuhan dan kehendak masyarakat, seperti dikeluarkannya Undang-Undang No 32 Tahun 2009 tentang Perlindungan dan Pengelolaan Lingkungan Hidup Pasal 1 ayat 30 menjelaskan tentang kearifan lokal yaitu nilai-nilai luhur yang berlaku dalam tata kehidupan masyarakat antara lain melindungi dan mengelola lingkungan hidup secara lestari dan ayat 31 menjelaskan tentang masyarakat hukum adat yaitu kelompok masyarakat yang secara turun temurun bermukim di wilayah geografis tertentu karena adanya ikatan pada asal usul leluhur, adanya hubungan yang kuat dengan lingkungan hidup, serta adanya sistem nilai yang menentukan pranata ekonomi, politik, sosial dan hukum.

Suhartini (2009) dalam penelitiannya menguraikan bahwa keanekaragaman pola-pola adaptasi terhadap lingkungan hidup yang ada dalam masyarakat Indonesia yang diwariskan secara turun temurun menjadi pedoman dalam memanfaatkan sumberdaya alam dan lingkungannya dikenal sebagai kearifan lokal suatu masyarakat dan melalui kearifan lokal ini masyarakat mampu bertahan menghadapi berbagai krisis yang menimpanya Maka dari itu, kearifan lokal penting untuk dikaji dan dilestarikan dalam suatu masyarakat guna menjaga keseimbangan dengan lingkungannya dan sekaligus dapat melestarikan lingkungannya.

Banyak kearifan lokal yang sampai saat ini terus menjadi panutan masyarakat antara lain di Jawa seperti pranoto mongso, nyabuk gunung yang menyarankan daerah pertanian ditanami tanaman untuk mencegah erosi dan membuat sengkedan mengikuti garis contour (Hadi, 2009). Menganggap Suatu Tempat Keramat); di Sulawesi (dalam bentuk larangan, ajakan, sanksi) dan di Badui dalam bentuk buyut dan pikukuh serta dasa sila). Kearifan lokal - kearifan lokal tersebut ikut berperan dalam pengelolaan sumberdaya alam dan lingkungannya (Suhartini, 2009). Tradisi subak di Bali yang menyalurkan air untuk pertanian, kearifan lokal zoning di Papua dan karuhan di tanah Sunda yang mengatur pengelolaan lahan hutan dan air kearifan lokal lubuk larangan yang digunakan untuk melestarikan wilayah sungai, danau dan waduk dalam batas tertentu.

\section{Eksistensi Hukum Adat Dimasa Depan}

Sejak Indonesia berdiri sebagai negara berdaulat, hukum adat menempati perannya sendiri dan dalam perkembangannya, huukum adat justeru mendapat tempat khusus dalam pembangunan hukum nasional. Dalam beberapa tahun 
belakangan di dalam pembentukan hukum negara pun, kebiasaan-kebiasaan (sering disebut kearifan local) yang hidup dalam masyarakat menjadi salah satu pertimbangan penting dalam pembentukan hukum negara, baik pada pembentukan Undang-Undang maupun dalam pembentukan peraturan daerah. Konsep pluralisme hukum tidak lagi tidak berkembang dalam ranah dikotomi antara sistem hukum negara (state law) di satu sisi dengan sistem hukum rakyat (folk law) dan hukum agama (religious law) di sisi yang lain. Pada tahap perkembangan ini, konsep pluralisme hukum lebih menekankan pada interaksi dan ko-eksistensi berbagai sistem hukum yang mempengaruhi bekerjanya norma, proses, dan institusi hukum dalam masyarakat.

Dalam hubungan ini I Nyoman menyatakan, bahwa hukum menjadi salah satu produk kebudayaan yang tak terpisahkan dengan segi-segi kebudayaan yang lain, seperti politik, ekonomi, struktur dan organisasi sosial, ideologi, religi, dll. Untuk memperlihatkan Perkembangan Pemikiran Konsep Pluralisme Hukum keterpautan hukum dengan aspek-aspek kebudayaan yang lain, maka menarik untuk mengungkapkan teori hukum sebagai suatu sistem (the legal system) yang diintroduksi Friedman seperti berikut:

a. Hukum sebagai suatu sistem pada pokoknya mempunyai 3 elemen, yaitu (a) struktur sistem hukum (structure of legal system) yang terdiri dari lembaga pembuat undangundang (legislatif), institusi pengadilan dengan strukturnya, lembaga kejaksaan dengan strukturnya, badan kepolisian negara, yang berfungsi sebagai aparat penegak hukum; (b) substansi sistem hukum (substance of legal system) yang berupa norma-norma hukum, peraturan-peraturan hukum, termasuk pola-pola perilaku masyarakat yang berada dibalik sistem hukum; dan (c) budaya hukum masyarakat (legal culture) seperti nilai-nilai, ide-ide, harapanharapan dan kepercayaan-kepercayaan yang terwujud dalam perilaku masyarakat dalam mempersepsikan hukum.

b. Setiap masyarakat memiliki struktur dan substansi hukum sendiri. Yang menentukan apakah substansi dan struktur hukum tersebut ditaati atau sebaliknya juga dilanggar adalah sikap dan perilaku sosial masyarakatnya, dan karena itu untuk memahami apakah hukum itu menjadi efektif atau tidak sangat tergantung pada kebiasaankebiasaan (customs), kultur (culture), tradisi-tradisi (traditions), dan norma-norma informal (informal norms) yang diciptakan dan dioperasionalkan dalam masyarakat yang bersangkutan.

Dalam Konteks Indonesia, hukum adat sesungguhnya adalah sistem hukum rakyat (folk law) khas Indonesia sebagai pengejawantahan dari the living law yang tumbuh dan berkembang berdampingan (co-existance) dengan sistem hukum lainnya yang hidup dalam negara Indonesia. Walau pun disadari hukum negara cenderung mendominasi dan pada keadaan tertentu terjadi juga, hukum negara menggusur, mengabaikan, atau memarjinalisasi eksistensi hak-hak masyarakat lokal dan sistem hukum rakyat (adat) pada tatanan implementasi dan penegakan hukum negara. 
Dengan memahami beberapa hal di atas dan dengan ada kebijakan dalam pembentukan Undang-Undang di Indonesia yang harus memperhatikan kearifan lokal, maka hal itu membuktikan sistem hukum adat akan berkembang dengan baik berdampingan dengan sistem hukum lainnya.

Sebenarnya dalam masyarakat adat di Indonesia tidak dikenal istilah "Hukum Adat" dan masyarakat hanya mengenal kata "adat" atau kebiasaan. Istilah "Hukum Adat" dikemukakan pertama kalinya oleh Cristian Snouck Hurgronye dalam bukunya yang berjudul "De Acheers" (orang-orang Aceh), yang kemudian diikuti oleh Cornelis van Vollen Hoven dalam bukunya yang berjudul "Het Adat Recht van Nederland Indie". Pemerintah Pemerintah Kolonial Belanda kemudian mempergunakan istilah hukum adat secara resmi pada akhir tahun 1929 dalam peraturan perundang-undangan Belanda.

Untuk melakukan kajian terhadap masa depan hukum adat di Indonesia pasca reformasi, maka ada baiknya kita review kembali apa yang dimaksud dengan hukum adat itu. Menurut B. Terhaar Bzn, hukum adat adalah keseluruhan peraturan yang menjelma dalam keputusan-keputusan dari kepala-kepala adat dan berlaku secara spontan dalam masyarakat. Dalam konteks ini Terhaar terkenal dengan teori "Keputusan" artinya bahwa untuk melihat apakah sesuatu adat-istiadat itu sudah merupakan hukum adat, maka perlu melihat dari sikap penguasa masyarakat hukum terhadap sipelanggar peraturan adat-istiadat Sementara itu menurut Cornelis van Vollen Hoven, hukum adat adalah keseluruhan aturan tingkah laku masyarakat yang berlaku dan mempunyai sanksi dan belum dikodifikasikan, sedangkan menurut J.H.P. Bellefroit Hukum adat sebagai peraturan-peraturan hidup yang meskipun tidak diundangkan oleh penguasa, tetapi tetap dihormati dan ditaati oleh rakyat dengan keyakinan bahwa peraturan-peraturan tersebut berlaku sebagai hukum.

Banyak lagi pendapat para sarjana terhadap apa yang disebut dengan hukum adat itu, dan beberapa pengertian yang telah dikemukakan di atas, hanyalah sekedar untuk melihat bagaimana masa depan hukum adat dimasa datang, setidaknya dengan bergulirnya reformasi di Indonesia termasuk reformasi bidang hukum. Ini tentu saja dengan berpegang pada apa yang dikemukakan Terhard, bahwa suatu adat akan menjadi hukum adat, apabila ada keputusan dari kepala adat dan apabila tidak ada keputusan maka itu tetap merupakan tingkah laku / adat.

Terlepas dari ada perbedaan pandangan dari para sarjana, yang pasti di Indonesia dikenal hukum adat dan dalam sistem hukum di Indonesia, sistem hukum adat hidup berdampingan dengan sistem hukum lainnya. Bagaimana hukum adat itu bisa tumbuh dan berkembang tidaklah tergantung pada kebijakan politik pemerintah dalam bidang hukum atau tergantung pada kemauan pembentuk Undang-Undang. Meskipun tidak disebut secara implicit, tetapi dari beberapa ketentuan konstitusi (UUD 1945) menyiratkan eksistensi hukum adat di Indonesia. Dan keberadaan hukum adat bukanlah karena adanya aturan peralihan UUD 1945. 
Mencermati batang tubuh UUD 1945, maka keberadaan hukum adat itu integral dengan rumusan Pasal 18B yang menyatakan; Negara mengakui dan menghormati kesatuan-kesatuan masyarakat hukum adat beserta hak-hak tradisionalnya sepanjang masih hidup dan sesuai dengan perkembangan masyarakat dan prinsip Negara Kesatuan Republik Indonesia, yang diatur dalam Undang-Undang. Pengakuan negara terhadap kesatuan masyarakat hukum adat itu sekaligus pengakuan terhadap hukum adatnya. Dengan demikian berlakunya hukum adat bukanlah tergantung kepada penguasa negara atau tergantung kepada kemuan politik penyelenggara negara, melainkan bagian dari kehendak konstitusi.

Bahkan, keberadaan hukum adat makin kuat dengan adanya deklarasi PBB tentang hak-hak masyarakat adat yang antara lain menyatakan; Mengakui dan menegaskan kembali bahwa warga-warga masyarakat adat diakui, tanpa perbedaan, dalam semua hak-hak asasi manusia yang diakui dalam hukum internasional, dan bahwa masyarakat adat memiliki hak-hak kolektif yang sangat diperlukan dalam kehidupan dan keberadaan mereka dan pembangunan yang utuh sebagai kelompok masyarakat. Masyarakat Adat mempunyai hak untuk menjaga dan memperkuat ciriciri mereka yang berbeda di bidang politik, hukum, ekonomi, sosial dan institusiinstitusi budaya, seraya tetap mempertahankan hak mereka untuk berpartisipasi secara penuh, jika mereka menghendaki, dalam kehidupan politik, ekonomi, sosial dan budaya Negara. Oleh sebab itu, dalam upaya melakukan reformasi hukum di Indonesia, tentu janganlah dilupakan, terutama berkaitan dengan menentukan paradigma pembaharuan konsep pembangunan hukum yang ada nilai-nilai yang tumbuh dalam masyarakat adat yang diakui secara konstitusional dan dalam deklarasi PBB.

Deklarasi PBB tersebut tentu tidak terlepas dari adanya indikasi, bahwa di banyak bagian dunia, masyarakat hukum adat ini tidak dapat menikmati hak-hak asasi mereka sederajat dengan penduduk lainnya di Negara tempat mereka tinggal, dan bahwa Undang-Undang, nilai-nilai, adat-istiadat, dan sudut pandang mereka sering kali telah terkikis. Dalam konvensi masyarakat hukum adat 1989 itu dinyatakan pula, bahwa masyarakat hukum adat di negara-negara merdeka yang dianggap sebagai pribumi karena mereka adalah keturunan dari penduduk yang mendiami negara yang bersangkutan, atau berdasarkan wilayah geografis tempat negara yang bersangkutan berada, pada waktu penaklukan atau penjajahan atau penetapan batas-batas negara saat ini dan yang, tanpa memandang status hukum mereka, tetap mempertahankan beberapa atau seluruh institusi sosial, ekonomi, budaya dan politik mereka sendiri.

Artinya, dimasa depan eksistensi hukum adat tidak hanya menjadi perhatian pembangunan hukum nasional, tetapi sekaligus akan menjadi pertimbanganpertimbangan dalam pergaulan dunia internasional. Khusunya dengan makin derasnya tuntutan globalisasi hukum yang terkadang, bahkan pada saat ini, tampak lebih berkembang dalam skala kepentingan hubungan ekonomi yang mereduksi 
kedaulatan hukum negara-negara nasional. Imbasnya tentu akan lebih berat terhadap hukum adat. Karena itu di dalam pembangunan hukum nasional, pemerintah harus memberikan tempat kepada tumbuh dan berkembangnya hukum adat dengan baik. Dengan deklarasi masyarakat hukum adat $1989 \mathrm{itu}$, sesungguhnya menjadi piranti bagi suatu negara, termasuk Indonesia dalam menekan penetrasi internasional, pada saat mana hukum nasional berkemungkinan tidak mampu melawan kuatnya tekanan dunia internasional. Bahkan konvesi masyarakat hukum adat itu menegaskan, pemerintah mempunyai tanggung jawab untuk menyusun, dengan partisipasi dari masyarakat hukum adat yang bersangkutan, aksi yang terkoordinasi dan sistematis untuk melindungi hak-hak dari masyarakat hukum adat ini dan untuk menjamin dihormatinya keutuhan mereka.

Dalam perspektif demikian, maka tidak ada alasan untuk mengambil sikap bahwa hukum negara dan atau globaliasi hukum atas nama kepentingan globalisasi lebih penting dari hukum adat. Disisi lain, dengan keterlibatan dunia internasional dalam menjaga eksistensi masyarakat hukum adat, maka ideology sentralisasi hukum, dimana hukum negara yang harus diberlakukan, sepertinya telah mengalami degradasi dan menjadi soal yang tidak boleh diabaikan dalam pembangunan hukum di Indonesia. Meskipun di pihak lain tidaklah menjadikan hukum adat mempersempit ruang gerak hukum negara (nasional). Ini sejalan dengan penegasan konvensi masyarakat hukum adat 1989 yang pada pasal 8-nya menegaskan, bahwa dalam memberlakukan peraturan perundang-undangan nasional kepada masyarakat hukum adat yang bersangkutan, adat-istiadat atau ketentuan-ketentuan hukum adat mereka harus diindahkan sebagaimana seharusnya.

Bagaimana kesepakatan-kesepakatan yang ditetapkan dalam UUD 1945 dan penegasan dalam konvensi masyarakat hukum adat 1989 itu terimplementasi di Indonesia, pada satu sisi selama ini hanya terlihat dalam beberapa peraturan perundang-undangan dan belum ada suatu ketentuan yang mengharuskan adanya kesadaran untuk memperhatikan hak-hak masyarakat hukum adat dalam setiap kali terjadi pembentukan peraturan perundang-undangan, bahkan ketika pembangunan hukum di Indonesia masih merupakan sub-sistem dari pembangunan politik, yang dirasakan hukum cenderung sebagai alat kekuasaan.

Dengan situasi dan kondisi demikian, maka pemerintah memberikan perhatian secara serius sehingga pemerintah mengeluarkan UU No.10 Tahun 2004 tentang Pembentukan Peraturan Perundang-undang setidaknya memberikan jaminan akan terpeliharanya nilai-nilai yang terdapat dalam masyarakat hukum adat atau terpelihara hukum adat di Indonesia. Dalam hubungan ini, selain dalam pembentukan hukum nasional diintrodisirnya sejumlah asas-asas pembentukan peraturan perundang-undangan jelas akan mempengaruhi pembentukan hukum di Indonesia di masa datang, termasuk dampaknya terhadap hukum adat. Pembentukan undang-undang sebagai salah satu bagian dari sistem hukum, yang 
berdasarkan UU No.10 Tahun 2004, maka materi muatan peraturan perundangundangan mengandung beberapa asas yang antaralain adalah asas bhineka tunggal ika. Asas materi muatan peraturan undang-undang ini, mengandung makna yang luas, dan sekaligus mengisaratkan masyarakat Indonesia yang pluralistik.

Asas bhineka Tunggal Ika tersebut integral dengan asas dapat dilaksanakan, dimana setiap Pembentukan Peraturan Perundang-undangan harus memperhitungkan efektivitas Peraturan Perundang-undangan tersebut di dalam masyarakat, baik secara filosofis, yuridis maupun sosiologis. Dalam konteks ini bisa dipahami, hukum negara bisa jadi tidak efektif apabila pembentukkannya mengabaikan keberadaan hukum adat suatu masyarakat.

Dilain pihak, sebagai konsekuensi dari penyelenggaraan Otonomi Daerah, maka daerah dapat mengakomodir hukum-hukum adat yang terdapat dalam wilayah terorialnya dalam peraturan daerah. Setidak-tidaknya peraturan daerah memberi legitimasi tentang keberlakuan hukum adat dalam wilayah teirotialnnya baik untuk sebagian maupun untuk seluruhnya. Bahkan pada tingkat pemerintahan lebih kecil lagi seperti Pemerintahan Nagari di Sumatera Barat, Pemerintah Nagari dapat menuangkan hukum adatnya yang tidak tertulis kedalam bentuk tertulis melalui Peraturan Nagari.

Peraturan perundang-undang nasional yang mengakomodasi hukum adat, atau peraturan perundang-undangan ditingkat daerah maupun pemerintah paling bawah sangatlah terbuka dan akomatif bagi perkembangan dan pertumbuhan hukum adat dan tidak tertutup kemungkinan hukum adat yang biasanya tidak tertulis akan berkembang secara pelahan-lahan secara tertulis.

Meskipun di sisi lain kita memahami banyak faktor yang mempengaruhi perkembangan hukum adat, disamping globalisasi, kemajuan zaman, ilmu pengetahuan dan teknologi, kondisi alam, juga faktor-faktor yang bersifat tradisional. Tetapi dalam perkembangannya saat ini, hukum adat telah memperlihatkan peranannya yang luar biasa dalam menyelesaikan dan memberi solusi dalam permasalahan sosial. Dari beberapa data penelitian, bahwa wilayah adat yang pengelolaan sumberdaya alamnya dikendalikan dan diurus secara otonom oleh komunitas-komunitas adat dengan menggunakan pranata adatnya ternyata mampu menjaga kelestarian multi-fungsi hutan. Realitas demikian merupakan pertanda optimisme bahwa masa depan keberlanjutan sumberdaya alam di Indonesia berada di tangan masyarakat adat yang berdaulat memelihara kearifan adat dan praktek-praktek pengelolaan sumberdaya alamnya. Sebagian dari masyarakat adat terbukti mampu menyangga kehidupan dan keselamatan mereka sendiri sebagai komunitas dan sekaligus menyangga layanan sosio-ekologis alam untuk kebutuhan seluruh mahluk, termasuk masyarakat lain di sekitarnya.

Lebih jauh dikemukakan, sistem-sistem lokal ini berbeda satu sama lain sesuai kondisi sosial budaya dan tipe ekosistem setempat. Penelitian yang pernah dilakukan Nababan (1995) di 4 propinsi (Kalimantan Timur, Maluku, Irian Jaya dan 
Nusan Tenggara Timur) menunjukkan bahwa walaupun sistem-sistem lokal ini berbeda satu sama lain namun secara umum bisa terlihat beberapa prinsip-prinsip kearifan tradisional yang dihormati dan dipraktekkan oleh kelompok-kelompok masyarakat adat, yaitu antara lain: sistem alokasi dan penegakan hukum adat untuk mengamankan sumberdaya milik bersama dari penggunaan berlebihan, baik oleh masyarakat sendiri maupun oleh orang luar komunitas.

Prinsip-prinsip ini berkembang secara evolusioner sebagai akumulasi dari temuan-temuan pengalaman masyarakat selama ratusan tahun. Karenanya, prinsipprinsip ini pun bersifat multi-dimensional dan terintegrasi dalam sistem religi, struktur sosial, hukum dan pranata atau institusi masyarakat adat yang bersangkutan. Kalau komunitas-komunitas masyarakat adat ini bisa membuktikan diri mampu bertahan hidup dengan sistem-sistem lokal yang ada, apakah tidak mungkin bahwa potensi sosial-budaya yang besar ini dikembalikan vitalitasnya dalam pengelolaan dan penyelesaian konflik sumberdaya alam dan sekaligus untuk menghentikan pengrusakan terhadap masyarakat adat di seluruh pelosok nusantara beserta habitatnya. Kearifan adat yang berbasis komunitas ini merupakan potensi sosial-budaya untuk direvitalisasi, diperkaya, diperkuat dan dikembangkan sebagai landasan baru menuju perubahan kebijakan yang tepat untuk tujuan keberlanjutan ekologis.

Dari fenomena di atas, setidaknya tampak, bagaimana kedayalakuan hukum adat dan masyarakat adat yang diyakini memiliki kemampuan yang memadai untuk melakukan rehabilitasi dan memulihkan kerusakan ekologis di areal-areal bekas konsesi HPH dan lahan-lahan hutan kritis (community-based reforestation and rehabilitation) dengan pohon-pohon jenis asli yang bermanfaat subsisten dan komersial. Efektivitas serupa itu belum tentu dimiliki oleh hukum nasional, sehingga hal ini member bukti bahwa hukum adat disamping beberapa faktor lainnya dalam masyarakat hukum adat memiliki potensi berkonstribusi dalam mewujukan tujuan dengan, dan hal itu tidak selalu dalam wajahnya yang tradisional. Hukum adat bisa tumbuh dan berkembang dalam masyarakat adatnya yang modern dan mesti menjadi perhatian yang sungguh-sungguh dari setiap pergerakkan globalisasi hukum, karena keberadaan hukum adat sudah menjadi bagian dari kesepakatan internasional.

\section{PENUTUP}

- Kebiasaan yang dilakukan anggota kelompok masyarakat Adat, baik Desa, wilayah Perkotaan / Kabupaten maupun Provinsi dan Negara sebagai tradisi leluhur nenek moyangnya secara turun-temurun yang diramu dalam suatu bingkai Adat Istiadat yang mengait dan mengikat.

- Adat Istiadat yang kuat dan dipertahankan oleh anggota kelompoknya mempu menggali kebiasaan masyarakat pada masa lalu, dan dapat mengangkat dan mempromosikan hal-hal yang dianggap pantas, disukai, 
dan diminati. Oleh karena punya daya tarik, unik dan punya nilai tersendiri dibanding yanglan. Keunikan tersebut menjadi unggulan (kearifan lokal) bagi masyarakat Adat yang bersangkutan

- Kearifan lokal merupakan kekhasan Adat Daerah yang bersangkutan sebagai ciri, tanda / lambang, Adat Daerahnya sebagai bukti kebesaran, kuat, dan kemasykurannya kearifan lokal tersebut. Sehingga kebesaran Adat Daeranya yang menjadi kebanggaan anggota kelompok Adatnya yang setiap anggotanya menjunjung tinggi dan menghormati serta mempertahankan Eksistensinyasetiap saat kapan dan dimanapun berada sepanjang masa.

\section{Daftar Pustaka}

Bushar Muhammad, Asas-Asas Hukum Adat (Suatu Pengantar), Pradnya Paramita, Jakarta: Tahun 1981.

Dewi C. Wulansari. Hukum Adat Indonesia Suatu Pengantar, Rineka Aditama, Bandung, 2010.

Departemen Agama RI, Hasil Penelitian Dasar IAIN Tahun 1980/1981 Agama Adat dan Pembangunan.

Dewi Wulan Sari, Prof, Hukum Adat Indonesia Suatu Pengantar, PT. Rafika Aditama, Tahun 2010.

Direktorat Jenderal Pembinaan Kelembagaan Agama Islam

Hasil Penelitian Dasar IAIN, Agama Adat Dan Pembangunan, Direktorat Jendral Pembinaan Kelembagaan Agama Islam Departemen Agama RI, Tahun 1981.

Husen Alting, Dinamika Hukum dalam Pengakuan dan Perlindungan Hak Masyarakat Hukum Adat Atas Tanah. Yogyakarta: LaksBang PRESSindo, 2010.

Komisi Nasional HAM, MK RI, Departemen Dalam Negeri RI. INVENTARIS DAN PERLINDUNGAN HAK MASYARAKAT HUKUM ADAT. Jakarta

Marco Manarisip. Jurnal EKSISTENSI PIDANA ADAT DALAM HUKUM NASIONAL. Lex Crimen Vol.I/No.4/Okt-Des/2012.

Soerjono, Dr, Kamus Hukum Adat, Penerbit Alumni, Bandung: Tahun 1978.

Soerojo Wignjodipoero, SH, Pengantar dan Asas-asas Hukum Adat, Gunung Agung, Jakarta: Tahun 1967.

Soerojo Wignjodipoero, SH, Kedudukan Serta Perkembangan Hukum Adat Setelah Kemerdekaan, Gunung Agung, Jakarta: Tahun 1982.

Soepomo, Hukum Adat, PT. Pradnya Paramita, Jakarta: Tahun 1989.

Soepomo, Sistem Hukum Di Indonesia Sebelum Perang Dunia II, Pradya Paramita, Jakarta: Tahun 1996.

Thalib, Suyuti, Hubungan Hukum Adat Dengan Hukum Islam, Perpustakaan UIN Sunan Kalijaga Yogyakarta, Tahun 2008. 
Yamin, Prof. Politik Agraria dalam Menyahuti Perkembangan Otonomi Daerah. Jurnal Konstitusi LK SPs Universitas Sumatera Utara, Vol. I, No. 2, November 2009 Wariyati, Sri, Memahami Hukum Adat, IAIN Surabaya, Surabaya: Tahun 2006.

Wulansari, Dewi, Hukum Adat Di Indonesia, PT. Refika Aditama, Bandung : Tahun 2010. 